Article

\title{
Magnetic Characterization of Chromium Intermediates in the Reduction of Chromium (VI) by Glutathione in Acidic Solutions
}

\author{
Roberto A. Marín ${ }^{1, *} \mathbb{B}$, Rathindra Bose ${ }^{1}$, Bogdan Dabrowski ${ }^{2}$ and Stanislaw Kolesnik ${ }^{2}$ \\ 1 Department of Chemistry and Biochemistry, Northern Illinois University, DeKalb, IL 60115, USA \\ 2 Department of Physics, Northern Illinois University, DeKalb, IL 60115, USA; dabrowski@anl.gov (B.D.); \\ kolesnik@niu.edu (S.K.) \\ * Correspondence: roberto@ingear.org; Tel.: +1-979-204-4761
}

Received: 26 April 2017; Accepted: 3 May 2018; Published: 17 May 2018

\begin{abstract}
Chromium (VI) is carcinogenic through intermediates formed in the cellular milieu by reduction with small reductants like glutathione (GSH), ascorbate, cysteine, and NADPH. Although the reduction of chromate by thiols has been investigated, the participation of $\mathrm{Cr}(\mathrm{IV})$ intermediates has been inferred only indirectly due to the $\mathrm{Cr}(\mathrm{IV})$ refractive behavior towards EPR spectroscopy. Biological data from numerous reports indicate that $\mathrm{Cr}(\mathrm{IV})$ is the species most likely responsible for the carcinogenicity of $\mathrm{Cr}(\mathrm{VI})$. Our kinetic studies suggested that in acidic solutions, glycine buffer at $\mathrm{pH} 2.8$, the reduction of chromate with GSH involves mostly a chromium(IV) intermediate. As a step towards the full characterization of the paramagnetic species involved in the reduction of chromate by thiols at neutral $\mathrm{pH}$, we embarked on an investigation of the reduction of chromate with GSH in glycine buffer at pH 2.8 using a Superconducting QUantum Interference Device (SQUID) magnetometer. Our results indicate a strong influence of temperature and confirm the presence of $\mathrm{Cr}(\mathrm{IV})$. At $2 \mathrm{~K}$, the saturation magnetization method was applied to the frozen reaction when it reached the peak of formation of intermediates and the contributions were calculated to be $30 \%$ of $\mathrm{Cr}(\mathrm{IV})$ and $69 \%$ of $\mathrm{Cr}(\mathrm{V})$. When the Curie-Weiss method was applied to determine the effective magnetic moment, the use of the linear portion of the curve, $100-200 \mathrm{~K}$, yielded $58 \% \mathrm{Cr}(\mathrm{IV})$ and $42 \% \mathrm{Cr}(\mathrm{V})$; when data from the region below the temperature of liquid $\mathrm{N}_{2}(77 \mathrm{~K})$ is employed, the intermediate is exclusively $\mathrm{Cr}(\mathrm{IV})$.
\end{abstract}

Keywords: chromium carcinogenesis; $\mathrm{Cr}(\mathrm{III}) ; \mathrm{Cr}(\mathrm{IV}) ; \mathrm{Cr}(\mathrm{V})$; $\mathrm{Cr}(\mathrm{VI})$; glutathione; SQUID; Magnetic Property Measuring System

\section{Introduction}

Chromium is known to cause lung cancer in workers of several industries [1]. The mechanism of carcinogenesis is associated with DNA damage from transient chromium species produced during the reduction of chromate. Indeed, DNA strand breaks and DNA oxidation catabolites [2-8] have been detected in in vivo studies with chromate, $\mathrm{Cr}(\mathrm{V})$, and $\mathrm{Cr}(\mathrm{IV})$ model compounds.

Glutathione, cysteine, and ascorbate are thought to be the main in vivo reductants. Interestingly, each of these produces a distinct combination of paramagnetic species: $\mathrm{Cr}(\mathrm{III}), \mathrm{Cr}(\mathrm{IV})$, and $\mathrm{Cr}(\mathrm{V})$ [9-11].

The carcinogenicity of $\mathrm{Cr}(\mathrm{VI})$ has been recently reviewed [12]. Besides affecting the lungs of workers exposed to dust-carrying $\mathrm{Cr}(\mathrm{VI})$ compounds, there is mounting evidence indicating that $\mathrm{Cr}(\mathrm{VI})$ causes cancers in the digestive tract upon oral exposure. During the reduction of $\mathrm{Cr}(\mathrm{VI}), \mathrm{Cr}(\mathrm{IV})$ appears to be the primary reactive species, and it is now accepted that the reduction probably starts during transport within the cell membrane, where chromate uptake is mediated by the CLIC carrier 
proteins. CLIC1 is a monomeric protein that belongs to the GST superfamily. The redox active site of CLIC1 is occupied by GSH. Glutathione is not only found in relatively high concentrations in the cellular milieu $(0.8-8.0 \mathrm{mM})$ [13], its concentration is 10-1000 times higher than that of other biological thiols that react faster with $\mathrm{Cr}(\mathrm{VI})$ [13]. It has been hypothesized that hexavalent $\mathrm{Cr}$ enters the cell and reacts with GSH in the CLIC within the cellular membrane, forming $\mathrm{Cr}(\mathrm{IV})$ and some $\mathrm{Cr}(\mathrm{V})$. Biological evidence also indicates that $\mathrm{Cr}(\mathrm{IV})$ - instead of $\mathrm{Cr}(\mathrm{V})$ - is the true carcinogen, as $\mathrm{Cr}(\mathrm{V})$ triggers cellular defense mechanisms including cell death and DNA repair processes [12], and $\mathrm{Cr}(\mathrm{IV})$ does not.

Ultimately, $\mathrm{Cr}(\mathrm{VI})$ is fully reduced to $\mathrm{Cr}(\mathrm{III})$ products within the cellular milieu [12]. It has been argued that a ligand exchange of these products with DNA and proteins causes primary, secondary, and tertiary adducts responsible for the carcinogenicity of $\mathrm{Cr}(\mathrm{VI})$ [14]. We have studied the $\mathrm{Cr}(\mathrm{V}) / \mathrm{Cr}(\mathrm{IV})$ and $\mathrm{Cr}(\mathrm{IV}) / \mathrm{Cr}(\mathrm{III})$ reduction processes [15] and know that $\mathrm{Cr}(\mathrm{IV})$ is more oxidizing than $\mathrm{Cr}(\mathrm{V})$; however, the reduction of $\mathrm{Cr}(\mathrm{IV})$ is slower. Therefore, we hypothesize that $\mathrm{Cr}(\mathrm{IV})$ intermediates accumulate and react with DNA and proteins forming adducts in which the metal is further reduced. Consistent with this framework, we recently reported on the detection of a wide (peak-to-peak separation $=260 \mathrm{G})$ EPR signal with a g value of 1.975 [16]. This species was detected during the reaction of the complex aquaethylenediaminebis(peroxo)chromium(IV) hydrate (I) (Figure 1) with GSH at neutral $\mathrm{pH}$. Interestingly, the signal was observed when nearly all of the $\mathrm{Cr}(\mathrm{V})$ species were depleted. Not surprisingly, Luo and Dalal [6] have also reported very broad Cr(IV) EPR signals.

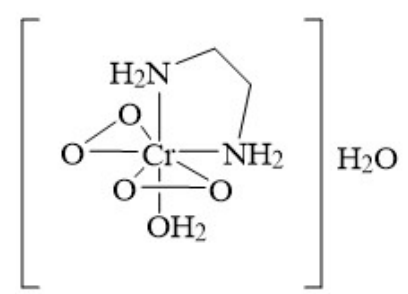

I

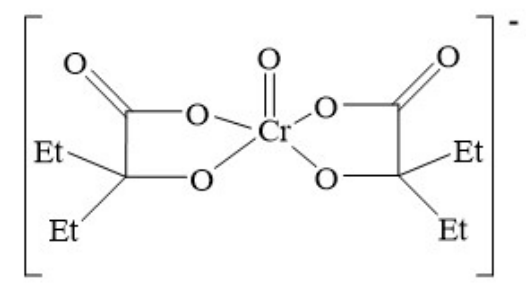

II

Figure 1. Aquaethylenediaminebis(peroxo)chromium(IV) hydrate (I) and (bis(2-hydroxy-2-ethylbutyrato) oxochromate(V) (II).

Several groups [9,17-22] have studied the reaction between $\mathrm{Cr}(\mathrm{VI})$ and glutathione (or related thiols). One common feature is that, regardless of $\mathrm{pH}$, the reaction proceeds through sequential one-electron transfers with the formation of one or more intermediates. At high $\mathrm{pH}$ values, various $\mathrm{Cr}(\mathrm{V})$ signals are detected by EPR, indicating both sluggishness and the involvement of parallel mechanisms. In order to gain insights into the involvement of $\mathrm{Cr}(\mathrm{IV})$ in these reactions, Bose et al. [9] studied the reaction between GSH and chromate at low $\mathrm{pH}$ values. Under the conditions of this study, the intermediate was characterized as mostly $\mathrm{Cr}(\mathrm{IV})$. Because, at ambient temperature, $\mathrm{Cr}(\mathrm{IV})$ is usually refractive to EPR spectroscopy, the study involved measurements of magnetic susceptibility using an NMR method developed by the author [22,23].

Here we present a report concerning our investigation of the reaction between chromate and glutathione at low $\mathrm{pH}$ using a Superconducting QUantum Interference Device (SQUID) magnetometer. Both the temperature-dependent magnetic susceptibility (via the Curie-Weiss Law) and the low-temperature isothermal magnetization (via saturation magnetization) curves were used to determine the oxidation state of the chromium intermediates. Our vision is twofold-to provide a clearer picture of the most likely carcinogen in chromium mediated DNA damage and to learn the chemical properties that differentiate the elusive $\mathrm{Cr}(\mathrm{IV})$ from the better known $\mathrm{Cr}(\mathrm{V})$ state. As a corollary, we expect to utilize the knowledge learned to develop catalytic systems (and possibly even chromium anti-cancer drugs). 


\section{Materials and Methods}

Reagents: Deuterated water $\left(\mathrm{D}_{2} \mathrm{O}\right)$, chromium potassium sulfate $\left[\mathrm{CrK}\left(\mathrm{SO}_{4}\right)_{2} \cdot 12 \mathrm{H}_{2} \mathrm{O}\right]$, anhydrous potassium chromate $\left(\mathrm{K}_{2} \mathrm{CrO}_{4}\right)$, reduced glutathione (GSH), and glycine (Gly) were purchased from Aldrich (Sigma-Aldrich, Saint Louis, MO, USA) and used as received.

Kinetic profiles: The absorbance vs. time data of a mixture containing $1.02 \pm 0.05 \mathrm{mM} \mathrm{Cr}$, $15.0 \pm 0.8 \mathrm{mM} \mathrm{GSH}$, and $100 \pm 5 \mathrm{mM} \mathrm{Gly} \mathrm{(pH} \mathrm{2.8)} \mathrm{were} \mathrm{measured} \mathrm{at} 460 \mathrm{~nm}$ with a Shimadzu UV160U spectrophotometer (Shimadzu Scientific Instruments, Columbia, MD., USA) at room temperature and subjected to iterative non-linear computer fitting using Sigma Stat (Systat Software Inc., San Jose, CA, USA) for Windows Version 3.5.

Magnetic Susceptibility Measurements: The Magnetic Property Measurement System (MPMS-7, Quantum Design, San Diego, CA, USA) was employed. The sample, $100 \mu \mathrm{L}$, was carried in a cuvette made from a $200 \mu \mathrm{L}$ PCR polypropylene tube. The magnetometer was calibrated by direct comparison of reference palladium samples originally purchased from the National Bureau of Standards (NBS Standard Reference Material 765) and provided by the manufacturer of the instrument-and the method was then tested against known $\mathrm{CrK}\left(\mathrm{SO}_{4}\right)_{2}$ samples [24]. In a typical experiment, the chromium stock solution and the mixture of glycine and fresh glutathione were bubbled separately with argon gas for $10 \mathrm{~min}$ in a glove box. The glutathione glycine mixture was then pipetted into the cuvette and mixed with enough chromium stock solution to make $100 \mu \mathrm{L}$. Once the cuvette was capped, the reaction was allowed to run until the peak of the biphasic kinetic profile was reached. At this time, the sample was submerged in liquid nitrogen and quickly placed in the airlock of the magnetometer, which was then purged to remove air and hence oxygen. Next it was lowered into the sample chamber, where a temperature of $70 \mathrm{~K}$ was maintained and centered inside a superconducting magnet to obtain the most accurate measurements. The same cuvette used to measure the sample was used to measure the control. When the control was measured, the (control) solution was added with a micro syringe until its weight matched the weight of the sample. All solutions were prepared in $\mathrm{D}_{2} \mathrm{O}$ to reduce the paramagnetic contribution of the proton nuclei of water whose nuclear paramagnetism (expressed as concentration of spins $\frac{1}{2}$ accounts for about $0.26 \mathrm{mM}$ ). Because of this, the deuteron's contribution was only $0.02 \mathrm{mM}$ [25]. A similar reason motivated the removal of oxygen from the samples. Initially, an $\mathrm{M}(\mathrm{H})$ curve was measured at $2 \mathrm{~K}$ to determine saturation magnetization. Right after this, a temperature dependence of magnetization was measured in the temperature range of 2-300 $\mathrm{K}$ to determine the material parameters according to the Curie-Weiss law. The same sequence of measurements was performed on the control solution, and the results of the control measurements were subtracted from the results of the Cr-containing solutions.

\section{Results}

The kinetic profile of the reaction between $1.0 \mathrm{mM} \mathrm{Cr}(\mathrm{VI})$ and $15 \mathrm{mM} \mathrm{GSH}$ in $100 \mathrm{mM}$ glycine buffer ( $\mathrm{pH}$ 2.8) is shown in Figure 2. As previously noticed $[9,22]$, this reaction is best described by a biphasic process:

$$
\mathrm{Cr}(\mathrm{VI})+\mathrm{GSH} \stackrel{k 1}{\rightarrow} \text { Intermediate } \stackrel{k 2}{\rightarrow} \text { Products }
$$

The concentration of the three absorbing components of the mixture can be represented by the following set of differential equations:

$$
\begin{gathered}
\mathrm{d}[\mathrm{Cr}(\mathrm{VI})] / \mathrm{dt}=-\mathrm{k}_{1}[\mathrm{Cr}(\mathrm{VI})] \\
\mathrm{d}[\text { Intermediate }] / \mathrm{dt}=\mathrm{k}_{1}[\mathrm{Cr}(\mathrm{VI})]-\mathrm{k}_{2}[\text { Intermediate }] \\
\mathrm{d}[\text { Products }] / \mathrm{dt}=\mathrm{k}_{2}[\text { Intermediate }]
\end{gathered}
$$


Assuming that the initial concentration of $\mathrm{Cr}$ is $[\mathrm{Cr}(\mathrm{VI})]_{\mathrm{o}}$ and that at time zero [intermediate] $=[$ Products $]=0$, the equations can be integrated to yield expressions for the concentration of each component over time:

$$
\begin{aligned}
& {[\mathrm{Cr}(\mathrm{VI})]=[\mathrm{Cr}(\mathrm{VI})]_{\mathrm{o}} \mathrm{e}^{-\mathrm{k}_{1} \mathrm{t}}} \\
& {[\text { Intermediate }]=\left[\mathrm{k}_{1} /\left(\mathrm{k}_{2}-\mathrm{k}_{1}\right)\right][\mathrm{Cr}(\mathrm{VI})]_{\mathrm{o}}\left(\mathrm{e}^{-\mathrm{k}_{1} \mathrm{t}}-\mathrm{e}^{-\mathrm{k}_{2} \mathrm{t}}\right)} \\
& {[\text { Products }]=[\mathrm{Cr}(\mathrm{VI})]_{\mathrm{o}}-[\mathrm{Cr}(\mathrm{VI})]-[\text { Intermediate }]}
\end{aligned}
$$

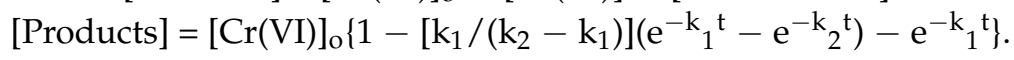

The time at the top of the curve of Figure 2 is given by

$$
t_{\text {top }}=\ln \left(k_{2} / k_{1}\right) /\left(k_{2}-k_{1}\right) .
$$

To obtain the rate constants, Equation (9) was fitted to the absorbance vs. time trace shown in Figure 2. In Equation (9), the first exponential corresponds to the rise of the intermediate, and the second exponential corresponds to its decay:

$$
A=a+b e^{-k_{1} t}+c e^{-k_{2} t} .
$$

Because $[\mathrm{Cr}(\mathrm{VI})]_{0}$ is known-and because the rate constants were obtained from the computer fitting of Equation (9) - the concentrations and the mole fractions of the components of the mixture were calculated by substitution in the above expressions. The results are given in Table 1.

Table 1. Distribution of chromium in the reaction between $\mathrm{Cr}(\mathrm{VI})$ and glutathione in $100 \mathrm{mM}$ glycine at the time when [Intermediate] is at maximum concentration $\left(\mathrm{t}_{\mathrm{top}}\right)$.

\begin{tabular}{ccc}
\hline$[\mathrm{GSH}] /[\mathrm{Cr}(\mathrm{VI})]$ & \multicolumn{2}{c}{15} \\
$\mathrm{~T}_{\text {top }} / \mathrm{s}$ & \multicolumn{2}{c}{200} \\
\hline$[\mathrm{Cr}(\mathrm{VI})]_{\mathrm{o}} / \mathrm{mM}$ & 1.02 & Mole Fraction \\
{$[\mathrm{Cr}(\mathrm{VI})]_{\text {top }} / \mathrm{mM}$} & 0.128 & 0.12 \\
{$[\text { Intermediate }]_{\text {top }} / \mathrm{mM}$} & 0.74 & 0.72 \\
{$[\text { Products }]_{\text {top }} / \mathrm{mM}$} & 0.155 & 0.15 \\
\hline
\end{tabular}

Figure 3 shows the magnetization of the frozen reaction of $\mathrm{Cr}(\mathrm{VI})$ and glutathione. The saturation magnetic moment of the reacted solution was $3.04 \mu_{\mathrm{B}}$, in agreement with the products being $\mathrm{Cr}(\mathrm{III})$. The saturation magnetic moment at the top of the kinetic profile was $1.39 \mu_{\mathrm{B}}$. To this value, each paramagnetic component of the mixture contributes according to its mole fraction at the time of measurement. In this respect, $\mathrm{Cr}(\mathrm{VI})$ is diamagnetic and negligibly contributes to the magnetic moment of the mixture. For the intermediate, there is a contribution of $2 \mu_{\mathrm{B}}$ per atom of $\mathrm{Cr}(\mathrm{IV})$ and $1 \mu_{\mathrm{B}}$ per atom of $\mathrm{Cr}(\mathrm{V})$, while the products contribute with $3 \mu_{\mathrm{B}}$ per $\mathrm{Cr}(\mathrm{III})$.

The expected saturation magnetic moment of the mixture at the top of the kinetic curve is calculated below (Table 2$)$ using the mole fractions ( $f_{\text {Intermediate, }} f_{\text {Products }}$ ) of the intermediate and the products in two limiting cases: the hypothetical case in which the intermediate is exclusively $\mathrm{Cr}(\mathrm{IV})$, and the hypothetical case in which the intermediate is exclusively $\mathrm{Cr}(\mathrm{V})$ :

Table 2. Expected saturation magnetic moment in the reaction between $\mathrm{Cr}(\mathrm{VI})$ and glutathione in $100 \mathrm{mM}$ glycine at the time when [Intermediate] is at maximum concentration ( $\left.\mathrm{t}_{\text {top }}\right)$.

\begin{tabular}{cc}
\hline & {$[\mathrm{Cr}(\mathrm{VI})] /[\mathrm{GSH}]=15$} \\
\hline Intermediate is only $\mathrm{Cr}(\mathrm{IV})$ & $\mathrm{M}=\mathrm{f}_{\text {Intermediate }} \mathrm{M}_{\mathrm{Cr}(\mathrm{IV})}+\mathrm{f}_{\text {Products }} \mathrm{M}_{\mathrm{Cr}(\mathrm{III})}$ \\
& $\mathrm{M}=0.72 \times 2 \mu_{\mathrm{B}}+0.15 \times 3 \mu_{\mathrm{B}}=1.9 \mu_{\mathrm{B}}$ \\
\hline Intermediate is only $\mathrm{Cr}(\mathrm{V})$ & $\mathrm{M}=\mathrm{f}_{\text {Intermediate }} \mathrm{M}_{\mathrm{Cr}(\mathrm{V})}+\mathrm{f}_{\text {Products }} \mathrm{M}_{\mathrm{Cr}(\mathrm{III})}$ \\
& $\mathrm{M}=0.72 \times 1 \mu_{\mathrm{B}}+0.15 \times 3 \mu_{\mathrm{B}}=1.2 \mu_{\mathrm{B}}$ \\
\hline
\end{tabular}


Because the experimental value of the saturation magnetization of the reaction was $1.39 \mu_{\mathrm{B}}$, the intermediate was neither $\mathrm{Cr}(\mathrm{IV})$ or $\mathrm{Cr}(\mathrm{V})$ alone. The contribution of $\mathrm{Cr}(\mathrm{IV})$ and $\mathrm{Cr}(\mathrm{V})$ was calculated to be $30 \%$ of $\mathrm{Cr}(\mathrm{IV})$ and $69 \%$ of $\mathrm{Cr}(\mathrm{V})$.

The Curie-Weiss curves of the frozen reaction, and of the reaction after it was allowed to react at room temperature for $12 \mathrm{~h}$, are shown in Figure 4 . Using the expression $\chi=\chi_{0}+\mu_{\text {eff }}^{2} / 8(\mathrm{~T}-$ $\theta)$, computer fittings of the experimental data were performed to estimate the effective magnetic moment. As is customarily done with pure and non-reactive samples, a fitting of the experimental data corresponding to the products was performed within the high-temperature portion of the curve (nominally from 100 to $200 \mathrm{~K}$ ), and the effective magnetic moment was $3.87 \mu_{\mathrm{B}}$. This value of $3.87 \mu_{\mathrm{B}}$ is in agreement with the expected value predicted by the spin only formula for a sample composed of $\mathrm{Cr}(\mathrm{III})$. To estimate the effective magnetic moments of the reacting sample, the fittings were performed using the data below the temperature of liquid nitrogen $(77 \mathrm{~K})$. The effective magnetic moment was determined to be $2.75 \mu_{\mathrm{B}}$. Next, we calculated the result assuming that the intermediate was only $\mathrm{Cr}(\mathrm{IV})$, and found that the effective magnetic moment would be $2.8 \mu_{\mathrm{B}}$ in this case (while if the intermediate were only $\mathrm{Cr}(\mathrm{V})$, the effective magnetic moment would be $\left.2.1 \mu_{\mathrm{B}}\right)$. Clearly, this value of $2.75 \mu_{\mathrm{B}}$ corresponds to a sample of only $\mathrm{Cr}(\mathrm{IV})$. If the fitting is performed within the high temperature range (as it was done with the reacted sample), the effective magnetic moment is $2.55 \mu_{B}$, which corresponds to $58 \% \mathrm{Cr}(\mathrm{IV})$ and $42 \% \mathrm{Cr}(\mathrm{V})$.

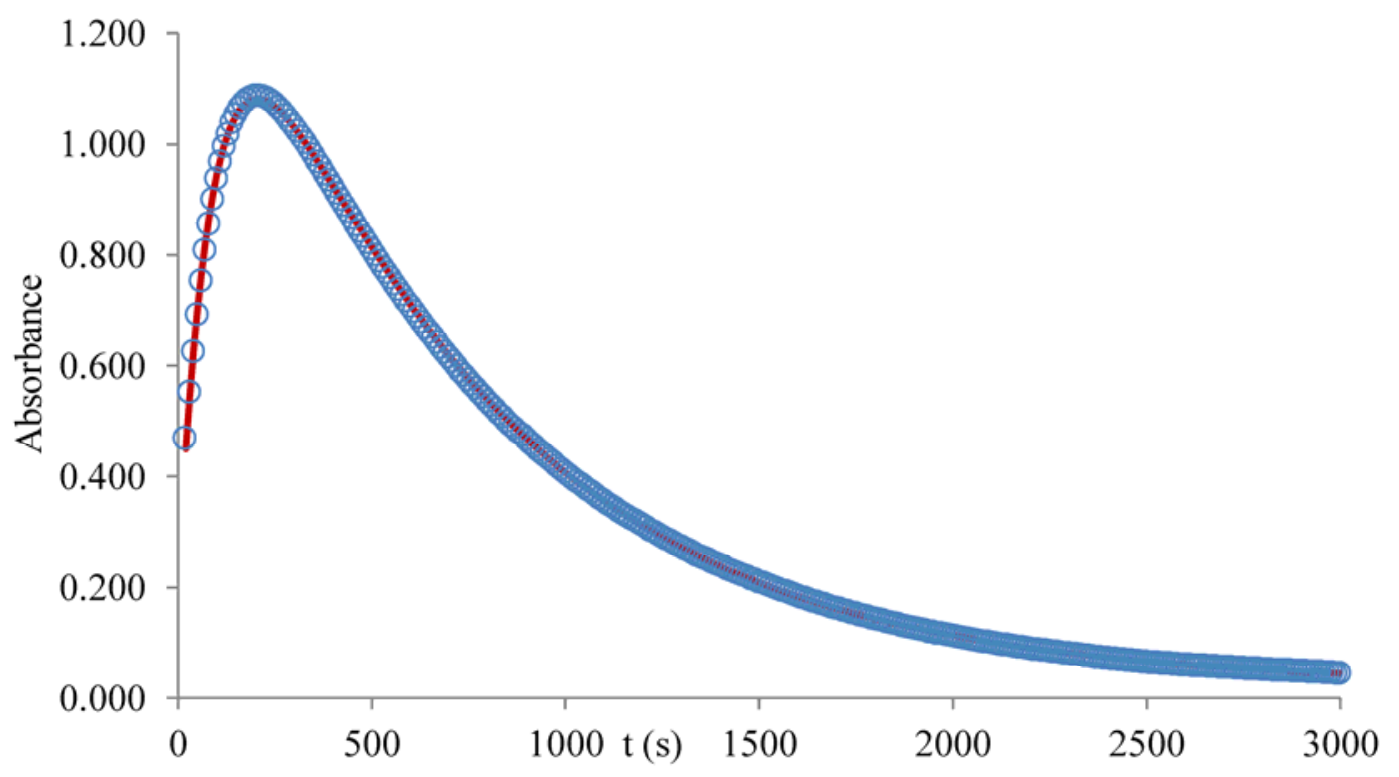

Figure 2. Observed (Circles) and simulated (solid line) absorbance-time trace at $460 \mathrm{~nm}$ of a mixture of $1.02 \pm 0.05 \mathrm{mM} \mathrm{Cr}(\mathrm{VI})$ and $15.0 \pm 0.8 \mathrm{mM}$ glutathione in $100 \mathrm{mM}$ glycine (pH 2.8). The calculated absorbances are based on Equation (9). The parameters used to plot the simulated curve are $\mathrm{a}=2.4 \times 10^{-2}, \mathrm{~b}=-1.4, \mathrm{k}_{1}=\left(1.0 \times 10^{-1}\right) \mathrm{s}^{-1}, \mathrm{c}=1.6$, and $\mathrm{k}_{2}=\left(1.5 \times 1^{-3}\right) \mathrm{s}^{-1}$. 


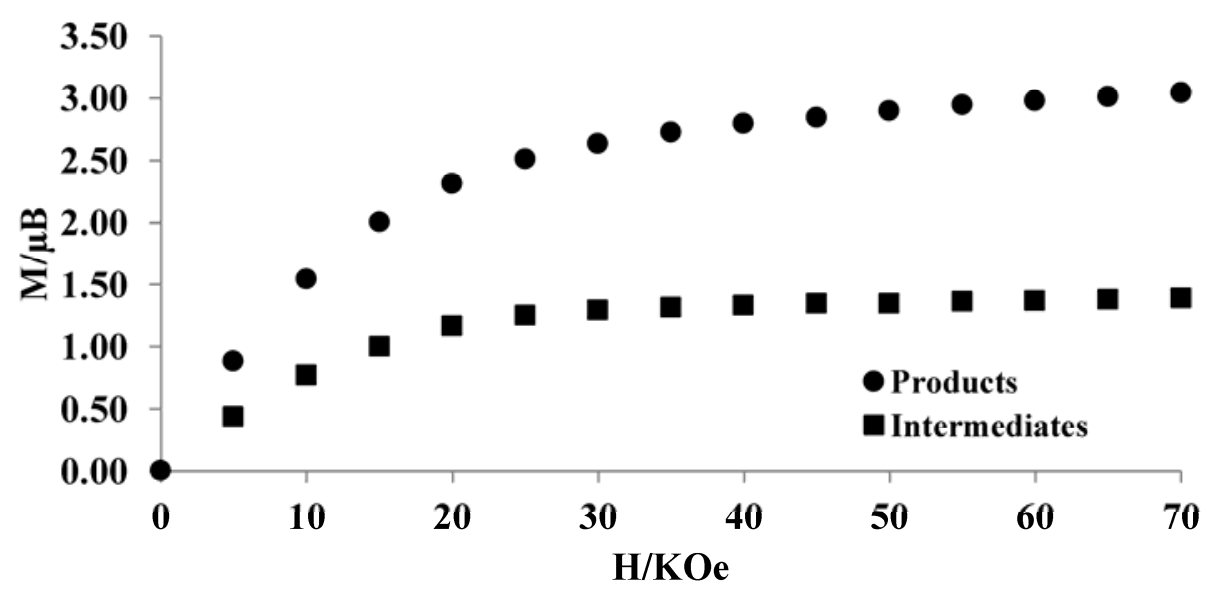

Figure 3. Isothermal $(2 \mathrm{~K})$ magnetization curves of the reaction of $1.02 \pm 0.05 \mathrm{mM} \mathrm{Cr}(\mathrm{VI})$ and $15.0 \pm 0.8 \mathrm{mM}$ GSH in $100 \mathrm{mM}$ glycine, $\mathrm{pH} 2.8$, in $\mathrm{D}_{2} \mathrm{O}$.

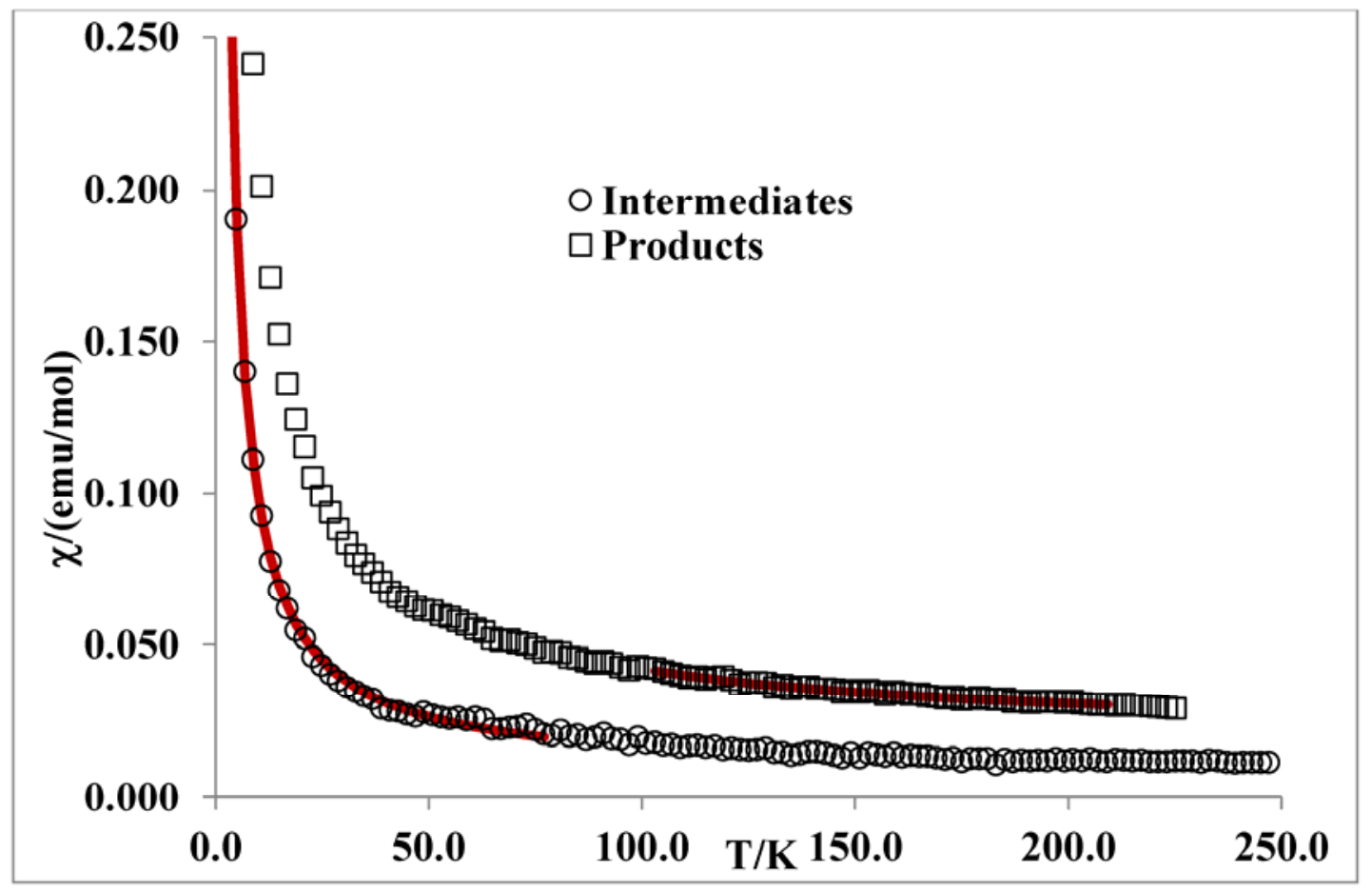

Figure 4. Observed (markers) and fitted (solid lines) magnetic susceptibility at $10 \mathrm{kOe}$ of the reaction of $1.02 \pm 0.05 \mathrm{mM} \mathrm{Cr}(\mathrm{VI})$ and $15 \pm 0.8 \mathrm{mM}$ glutathione in $100 \mathrm{mM}$ glycine. The fitting was done using the equation $\chi=\chi_{0}+\mu_{\mathrm{eff}}{ }^{2} / 8(\mathrm{~T}-\theta)$. The obtained fitting parameters are $\chi_{0}=7.44 \times 10^{-3} \mathrm{emu} / \mathrm{mol}$, $\mu_{\text {eff }}=2.75 \mu_{\mathrm{B}}$, and $\theta=-0.276 \mathrm{~K}$ for the intermediates, and $2.075 \times 10^{-2} \mathrm{emu} / \mathrm{moL}, \mu_{\mathrm{eff}}=3.87 \mu_{\mathrm{B}}$, and $\theta=12.88 \mathrm{~K}$ for the products.

\section{Discussion}

In the original study [9], with an excess of oxidized glutathione at $\mathrm{pH} 2.7$, the chromium (VI) vs. glutathione reaction showed two chromatographic peaks that grew and then decayed. The two peaks showed a maximum absorption at $460 \mathrm{~nm}$. At this wavelength, none of the reagents or products absorbed, and these peaks were assigned to intermediates [9]. The reaction produced only $\mathrm{Cr}$ (III) as evidenced by the UV-VIS spectrum of the mixture at the end of the reaction. The main bands were centered at $572\left(\varepsilon=33 \mathrm{M}^{-1} \mathrm{~cm}^{-1}\right)$ and $408 \mathrm{~nm}\left(\varepsilon=26 \mathrm{M}^{-1} \mathrm{~cm}^{-1}\right)$. The EPR of the reaction mixture 
showed a weak peak with a g value of 1.989 . When compared with an authentic $\mathrm{Cr}$ (V) complex (II) (bis(2-hydroxy-2-ethylbutyrato)oxochromate(V), $\mathrm{g}=1998$ ) (Figure 1), this complex produced an intense signal even at $0.5 \mathrm{mM}$ in an acidic solution. Using the intensity of this complex as a calibration point, it was estimated that, among the intermediates, less than $3 \%$ of the total chromium was $\mathrm{Cr}(\mathrm{V})$. When the same reaction was performed in the absence of excess oxidized glutathione and in a glycine buffer, only one intermediate was detected by HPLC, and the EPR experiments did not show evidence of $\mathrm{Cr}(\mathrm{V})$ at $\mathrm{pH}$ values lower than 3.4 [22]. In order to further characterize the EPR silent intermediate, time course magnetic susceptibility measurements by NMR were performed. These experiments gave effective magnetic moments of $2.6 \mu_{\mathrm{B}}$ for the intermediates and $4.3 \mu_{\mathrm{B}}$ for the products, which led to the conclusion that the intermediates were exclusively $\mathrm{Cr}(\mathrm{IV})$. This result has been disputed with the argument that a mixture of $\mathrm{Cr}(\mathrm{VI})$ and $\mathrm{Cr}(\mathrm{III})$ can produce the same magnetic moments. However, the kinetic profile of this reaction clearly indicates the presence of an intermediate that decays slowly, so the magnetic properties of the mixture cannot be attributed to a combination of starting materials and products. One possibility is that the intermediate is a $\mathrm{Cr}(\mathrm{VI})-\mathrm{GSH}$ complex, as Lay et al. [26] have proposed. This would be consistent with the lack of detection of $\mathrm{Cr}(\mathrm{V})$ EPR signals. However, if the intermediate were a $\mathrm{Cr}(\mathrm{VI})-\mathrm{GSH}$ complex, the saturation magnetic moment would be $0.45 \mu_{\mathrm{B}}$-instead of the $1.4 \mu_{\mathrm{B}}$ that we measured-and the expected effective magnetic moment would be $1.5 \mu_{\mathrm{B}}$. The values of the saturation magnetic moment and the effective magnetic moment obtained in this work are helpful for clarifying one fact: that the intermediate in this reaction is not a $\mathrm{Cr}(\mathrm{VI})-\mathrm{GSH}$ complex. A larger effective magnetic moment than the saturation magnetic moment is consistent with a larger proportion of $\mathrm{Cr}(\mathrm{IV})$ at temperatures higher than $2 \mathrm{~K}$. This is evidence that the reduction of chromate by glutathione progresses in steps of one-electron, $\mathrm{Cr}(\mathrm{VI}) \rightarrow \mathrm{Cr}(\mathrm{V}) \rightarrow \mathrm{Cr}(\mathrm{IV}) \rightarrow \mathrm{Cr}(\mathrm{III})$. However, because of the fact that $\mathrm{Cr}(\mathrm{IV})$ normally does not give EPR signals at room temperature, the lack of detection of $\mathrm{Cr}(\mathrm{V})$ signals with EPR is only indicative of how fast the process goes from $\mathrm{Cr}(\mathrm{VI})$ to $\mathrm{Cr}(\mathrm{IV})$. In brief, the reaction proceeds in one-electron steps with a long-lived $\mathrm{Cr}(\mathrm{IV})$ intermediate as originally proposed.

\section{Conclusions}

We have shown that the magneto-chemical technique is suitable for the characterization of the reduction of chromate by biological reductants. The worthiness of this instrumental approach is evident when it is considered that $\mathrm{Cr}(\mathrm{IV})$ is typically not EPR active at ambient temperature. Moreover, the UV spectroscopy technique is not specific enough, especially when it is noted that these reactions produce more than one intermediate. In fact, in our [16] ESI-MS, cyclic voltammetry, EPR, and HPLC studies of the reaction between aquaethylenediaminebis(peroxo)chromium(IV) hydrate (I) with GSH at neutral $\mathrm{pH}$, we detected multiple intermediates of $\mathrm{Cr}(\mathrm{IV})$ and $\mathrm{Cr}(\mathrm{V})$ (mono and multi-ligated $\mathrm{Cr}$-GSH species). Some researchers, including Bose et al. [9], Marin et al. [16], Liu et al. [27], and Ramsey and Dalal [28], have paid attention to the potentially essential role of $\mathrm{Cr}(\mathrm{IV})$ in chromium carcinogenesis. Considering that the DNA damage caused by $\mathrm{Cr}(\mathrm{IV})$ does not trigger the cellular defense mechanisms that occur with $\mathrm{Cr}(\mathrm{V})$ and $\mathrm{Cr}(\mathrm{IV}), \mathrm{Cr}(\mathrm{IV})$ is likely the most potent carcinogen through altered survivor cells leading to cancer [12].

In this work, the difference between magneto-chemical measurements at $2 \mathrm{~K}$ and those at higher temperatures leads to two questions: (1) At what temperature does the advancement of the reaction in the frozen mixture occur? (2) What are the mechanism(s) responsible for this? The facilitation of reactions at various $\mathrm{pH}$ values as well as the measurement of the magnetism at various times over the kinetic profile are next steps in further magneto-chemical investigations of this system.

Author Contributions: R.A.M. and R.B. conceived the experiments; R.A.M. and S.K. designed the experiments; R.A.M. and S.K. performed the experiments; R.A.M. and S.K. analyzed the data; R.B. and B.D. contributed reagents/materials/analysis tools; R.A.M. interpreted the data and wrote the paper.

Acknowledgments: The authors thank Northern Illinois University for financial support.

Conflicts of Interest: The authors declare no conflict of interest. 


\section{References}

1. International Agency for Research on Cancer (IARC). Chromium, nickel and welding. In Monographs on the Evaluation of Carcinogenic Risks in Humans; IARC: Lyon, France, 1990; Volume 49, pp. 1-648.

2. Bose, R.N.; Fonkeng, B.S.; Moghaddas, S.; Stroup, D. Mechanisms of DNA damage by $\operatorname{chromium(V)}$ carcinogens. Nucleic Acids Res. 1998, 26, 1588-1596. [CrossRef] [PubMed]

3. Bose, R.N.; Moghaddas, S.; Mazzer, P.A.; Dudones, L.P.; Joudah, L.; Stroup, D. Oxidative damage of DNA by chromium(V) complexes: Relative importance of base versus sugar oxidation. Nucleic Acids Res. 1999, 27, 2219-2226. [CrossRef] [PubMed]

4. Joudah, L.; Moghaddas, S.; Bose, R.N. DNA oxidation by peroxo-chromium(V) species: Oxidation of guanosine to guanidinohydantoin. Chem. Commun. 2002, 16, 1742-1743. [CrossRef]

5. Hai, L.; Youngde, L.; Xianglin, S.; Yan, M.; Nar, S.D. Chromium(IV)-Mediated Fenton-like Reaction Causes DNA Damage: Implication to Genotoxicity of Chromate. Ann. Clin. Lab. Sci. 1996, 26, 185-191.

6. Hai, L.; Youngde, L.; Yan, M.; Xianglin, S.; Nar, S.D. Role of Chromium(IV) in the Chromium(VI)-Related Free Radical Formation, dG Hydroxylation, and DNA Damage. J. Inorg. Biochem. 1996, 64, 25-35.

7. Casadevall, M.; Da Cruz Fresco, P.; Kortemkamp, A. Chromium(VI)-Mediated DNA damage: Oxidative pathways resulting in the formation of DNA breaks and abasic sites. Chem.-Biol. Interact. 1999, 123, 117-132. [CrossRef]

8. Slade, P.G.; Hailer, M.K.; Martin, B.D.; Sugden, K.D. Guanine-Specific Oxidation of Double-Stranded DNA by $\mathrm{Cr}(\mathrm{VI})$ and Ascorbic Acid Forms Spiroiminodihydantoin and 8-Oxo-2'-deoxyguanosine. Chem. Res. Toxicol. 2005, 18, 1140-1149. [CrossRef] [PubMed]

9. Bose, R.N.; Moghaddas, S.; Gelerinter, E. Long-Lived Chromium(IV) and Chromium(V) Metabolites in the Chromium(VI)-Glutathione Reaction: NMR, ESR, HPLC, and Kinetic Characterization. Inorg. Chem. 1992, 31, 1987-1994. [CrossRef]

10. Stearns, D.M.; Wetterhahn, K.E. Reaction of Chromium(VI) with Ascorbate Produces Chromium(V), Chromium(IV), and Carbon-Based Radicals. Chem. Res. Toxicol. 1994, 7, 219-230. [CrossRef] [PubMed]

11. Chiu, A.; Chiu, N.; Shi, X.; Beaubier, J.; Dalal, N. Activation of a Procarcinogen by Reduction: $\mathrm{Cr}(\mathrm{VI})-\mathrm{Cr}(\mathrm{V})-\mathrm{Cr}(\mathrm{IV})-\mathrm{Cr}(\mathrm{III})$ A Case Study by Electron Spin Resonance (ESR/PMR). J. Environ. Sci. Health Part C Environ. Carcinog. Ecotoxicol. Rev. 1999, 16, 135-148. [CrossRef]

12. Chiu, A.; Shi, J.; Lee, W.K.P.; Hill, R.; Wakeman, T.P.; Katz, A.; Xu, B.; Dalal, N.S.; Robertson, J.D.; Chen, C.; et al. Review of Chromium (VI) Apoptosis, Cell-Cycle-Arrest, and Carcinogenesis. J. Environ. Sci. Health Part C Environ. Carcinog. Ecotoxicol. Rev. 2010, 28, 188-230. [CrossRef] [PubMed]

13. Connett, P.H.; Wetterhahn, K.E. Metabolism of the Carcinogen Chromate by Cellular Constituents. Struct. Bond. 1983, 54, 93-124.

14. Macfie, A.; Hagan, E.; Zhitkovich, A. Mechanism of DNA-Protein Cross-Linking by Chromium. Chem. Res. Toxicol. 2010, 23, 341-347. [CrossRef] [PubMed]

15. Bose, R.N.; Fonkeng, B.; Barr-David, G.; Farrell, R.P.; Judd, R.J.; Lay, P.A.; Sangster, D.F. Redox Potentials of Chromium(V)/(IV), -(V)/(III), and -(IV)/(III) Complexes with 2-Ethyl-2-hydroxybutanoato(2-/1-) Ligands. J. Am. Chem. Soc. 1996, 118, 7139-7144. [CrossRef]

16. Marin, R.; Ahuja, Y.; Jackson, G.P.; Laskay, U.; Bose, R.N. Potentially Deadly Carcinogenic Chromium Redox Cycle Involving Peroxochromium(IV) and Glutathione. J. Am. Chem. Soc. 2010, 132, 10617-10619. [CrossRef] [PubMed]

17. McAuley, A.; Olatunji, M.A. Metal-ion oxidations in solutions. Part XVIII. Characterization, rates and mechanism of formation of the intermediates in the oxidation of thiols by chromium(VI). Can. J. Chem. 1977, 55, 3328-3334. [CrossRef]

18. Connett, P.H.; Wetterhahn, K.E. In Vitro Reaction of the Carcinogen Chromate with Cellular Thiols and Carboxylic Acids. J. Am. Chem. Soc. 1985, 107, 4282-4288. [CrossRef]

19. O'Brien, P.; Wang, G.; Wyatt, P.B. Studies of the Kinetics of the Reduction of Chromate by Glutathione and Related Thiols. Polyhedron 1992, 11, 3211-3216. [CrossRef]

20. Kwong, D.W.J.; Pennington, D.E. Stoichiometry, Kinetics, and Mechanisms of the Chromium(VI) Oxidation of L-Cysteine at Neutral pH. Inorg. Chem. 1984, 23, 2528-2532. [CrossRef]

21. Lay, P.A.; Levina, A. Kinetics and Mechanism of Chromium(VI) Reduction to Chromium(III) by L-Cysteine in Neutral Aqueous Solutions. Inorg. Chem. 1996, 35, 7709-7717. [CrossRef] 
22. Moghaddas, S.; Gelerinter, E.; Bose, R.N. Mechanisms of Formation and Decomposition of Hypervalent Chromium Metabolites in the Glutathione-Chromium (VI) Reaction. J. Inorg. Biochem. 1995, 57, 135-146. [CrossRef]

23. Bose, R.N.; Li, D.; Moghaddas, S. Kinetic Method Based on Nuclear Magnetic Resonance Measurements. Anal. Chem. 1991, 63, 2757-2762. [CrossRef]

24. Warren, H.E. Spin Paramagnetism of $\mathrm{Cr}^{+++}, \mathrm{Fe}^{+++}$, and $\mathrm{Gd}^{+++}$at Liquid Helium Temperatures and in Strong Magnetic Fields. Phys. Rev. 1952, 88, 559-562.

25. Day, E.P.; Kent, T.A.; Lindahl, P.A.; Munck, E. Squid Measurement of Metalloprotein Magnetization. Biophys. J. 1987, 52, 837-853. [CrossRef]

26. Levina, A.; Lay, P.A. Solution Structures of Chromium(VI) Complexes with Glutathione and Model Thiols. Inorg. Chem. 2004, 43, 324-335. [CrossRef] [PubMed]

27. Liu, K.J.; Shi, X.; Dalal, N.S. Synthesis of Cr(IV)-GSH, Its Identification and Its Free Hydroxyl Radical Generation: A Model Compound for Cr(VI) Carcinogenicity. Biochem. Biophys. Res. Commun. 1997, 235, 54-58. [CrossRef] [PubMed]

28. Ramsery, C.M.; Dalal, N.S. Crystalline and water soluble $\mathrm{Cr}(4+)$ and $\mathrm{Cr}(5+)$ model compounds for chromium toxicity studies. Mol. Cell. Biochem. 2004, 255, 113-118. [CrossRef]

(C) 2018 by the authors. Licensee MDPI, Basel, Switzerland. This article is an open access article distributed under the terms and conditions of the Creative Commons Attribution (CC BY) license (http:/ / creativecommons.org/licenses/by/4.0/). 